\title{
Physical Properties and Antibacterial Activities of Spray Footsanitizer Combination of Coffee Seed and Ginger Extract with Variation of Stirring Speed
}

\author{
Wilda Amananti ${ }^{1}$, Dairoh ${ }^{2}$ \\ \{amanantiwilda@yahoo.com ${ }^{1}$ \} \\ DIII Farmasi, Politeknik Harapan Bersama, 52147, Indonesia ${ }^{1,2}$
}

\begin{abstract}
Foot odor is a matter of body odor. This physical disorder is called bromhidrosis, bromhidrosis is excessive body odor due to the secretions of apocrine sweat glands found in the armpits, scalp, soles of the feet, between the fingers and genitals. Prevention efforts can use antibacterial soap. However, this attempt is impractical. a more practical foot deodorizing innovation, namely the Footsanitizer Spray. Footsanitizer Spray on the market contains $70-95 \%$ alcohol. it is necessary to have natural ingredients that can act as antibacteria, namely coffee beans and ginger rhizome. The formulation of Footsanitizer Spray, a combination of coffee bean extract and ginger root, was successfully formulated. Based on organicoleptic testing, all Footsanitizer Spray formulas are liquid, light brown in color, have a distinctive aromatic smell and have a soft taste. foot sanitizer has good clarity and homogeneity. The results of the specific gravity test for the three formulas, namely formula 1, formula 2 and formula 3 are 1,043 grams / $\mathrm{ml}, 1,060 \mathrm{grams} / \mathrm{ml}$, and 1,067 grams / $\mathrm{ml}$, respectively. Meanwhile, the viscosity values of each are $1.91 \mathrm{cp}, 1.63 \mathrm{cp}$, and $1.58 \mathrm{cp}$. formula 3 with stirring $1500 \mathrm{rpm}$ has better antibacterial activity than other formulas.
\end{abstract}

Keywords: Foot sanitizer spray, physical properties and antibacterial activities

\section{Introduction}

Foot odor is one of the most common body odor problems. This physical disorder is one of the habitual disorders of apocrine sweat and has the term Bromhidrosis, Bromhidrosis is a condition where a person's body odor is excessive than normal due to the secretion of apocrine sweat glands located in the armpits, scalp, soles of the feet, between the fingers, and genitals [1]. Prevention efforts can start from cleaning the feet using antibacterial soap and changing socks that are dirty or smelly [2]. However, these efforts are considered impractical. So, it is necessary to have a more practical foot deodorizing innovation, namely Foot Sanitizer Spray. Foot sanitizer Spray in the market contains 70-95\% alcohol. The active ingredient contains alcohol as an antibacterial because it has the highest effectiveness against bacteria. Excessive use of alcohol and chemicals can have health effects and irritant effects on the skin. Therefore, its use needs to be reduced by adding active ingredients from natural ingredients that can act as antibacterial, namely coffee beans and Ginger rhizomes.

Coffee is known to contain caffeine which has many benefits for the beauty and health of the human body. Apart from that, coffee also has properties that are known to remove bad odors[3]. Ginger (Zingiber officinale Roscoe) has been known to have antibacterial activity 
because it contains phenols, flavonoids, terpenoids, and essential oils [4]. Ginger rhizome has antibacterial activity against Propionibacterium acnes, Pseudomonas aeruginosa, Staphylococcus aureus, and Staphylococcus epidermidis [5].

Stirring in the process of making Foot sanitizer Spray has an important role because it will have an impact on the physical properties of the preparation [2]. In this article, we will review the foot sanitizer Spray formulation with varying stirring speeds and review its physical properties and antibacterial activity. This article also examines how the effect of stirring speed on the physical properties and antibacterial activity of foot sanitizer Spray.

\section{Methods}

\subsection{Extraction of coffee and ginger}

Ginger extract was made by maceration method. Maceration method is used because maceration is a simple method of extraction, easy operation, simple tools that only need a soaking vessel, relatively low operating costs, relatively efficient process and no heating. The sprays used were $70 \%$ ethanol [5]. Using $70 \%$ ethanol is because $70 \%$ ethanol is very effective in producing the optimal amount of active ingredients. The spreader used for maceration was 1 liter of $70 \%$ ethanol into 100 grams of each ginger and coffee powder.

Maceration is done by soaking 100 grams of ginger root and coffee beans in 1 liter of $70 \%$ ethanol, then shaking it for 6 hours using a shaker and leaving it for 18 hours. The maserate is filtered using a vacuum filter and then separated from the pulp. The pulp is macerated again and filtered again 2 times in the same way. All maserate collected was concentrated by means of a rotary evaporator at a temperature of $600 \mathrm{C}$ at a speed of $50 \mathrm{rpm}$.

\subsection{Making footsanitizer spray}

The results of ginger and coffee rhizome extract are used as active ingredients in the preparation of Footsanitizer Spray for three formulas, namely with the difference in the stirring speed of Formula $1500 \mathrm{rpm}$, Formula $21000 \mathrm{rpm}$ and Formula $31500 \mathrm{rpm}$, each formula is made with the composition of the ratio of ginger and coffee in the formula. $35 \%$ : $35 \%$. The preparation of the Footsanitizer Spray formula is carried out by mixing the respective ingredients of Ginger Extract and Coffee Bean Extract as the active substance. Then add 10\% glycerin, $0.2 \%$ methyl paraben and add ethanol to $50 \mathrm{ml}$. Table 1 shows the Footsanitizer Spray formula. materials used in the manufacture of Footsanitizer spray formulas, among others Ginger Extract 35\%, Coffee Extract 35\%, Glycerin 20\%, Methyl Paraben 0,2\%, Ethanol 70\% $50 \mathrm{ml}$. Testing the physical properties of Foot Sanitizer Spray. The physical properties of the preparation include tests of homogeneity, $\mathrm{pH}$, viscosity and density. In this study, antibacterial activity was tested.

\section{Results and Discussion}

Foot Sanitizer Spray is made into three formulas (see Table 1), namely based on the difference in the stirring speed of Formula $1500 \mathrm{rpm}$, Formula $21000 \mathrm{rpm}$ and Formula 31500 $\mathrm{rpm}$. Each formula is made with the composition of the ratio of ginger and coffee in Formula 
35\%: $35 \%$. The preparation of the Foot Sanitizer Spray formula is carried out by mixing the respective ingredients of Ginger Extract and Coffee Bean Extract as the active substance. Then add $10 \%$ glycerin, $0.2 \%$ methyl paraben and add ethanol to $50 \mathrm{ml}$.

Table. 1 Foot sanitizer Spray Organoleptic Test Results

\begin{tabular}{|c|c|c|c|c|c|c|c|c|}
\hline $\begin{array}{l}\text { Materi } \\
\text { al }\end{array}$ & $\begin{array}{l}\text { Fo } \\
\text { r } \\
\text { m } \\
\text { ul } \\
\text { a } \\
\end{array}$ & $\begin{array}{l}\text { Organoleptic } \\
\text { Test Results }\end{array}$ & $\begin{array}{l}\text { PH } \\
\text { Val } \\
\text { ue }\end{array}$ & $\begin{array}{l}\text { Clarity } \\
\text { Testing } \\
\text { Results }\end{array}$ & $\begin{array}{l}\text { Homogen } \\
\text { eity test } \\
\text { results }\end{array}$ & $\begin{array}{l}\text { Density value } \\
\text { (gram/ml) }\end{array}$ & $\begin{array}{l}\text { Viscosit } \\
\text { y value } \\
(\mathrm{Cp})\end{array}$ & $\begin{array}{l}\text { Area of } \\
\text { Obstacl } \\
\text { e }\left(\mathrm{mm}^{2}\right)\end{array}$ \\
\hline \multirow{3}{*}{$\begin{array}{l}\text { Ginger } \\
: \\
\text { Coffee } \\
35 \%: 3 \\
5 \%\end{array}$} & 1 & $\begin{array}{l}\text { Shape : Liquid } \\
\text { Color: Dark } \\
\text { brown } \\
\text { Smell: Aromatic } \\
\text { Typical } \\
\text { Taste : Soft not } \\
\text { sticky }\end{array}$ & 6 & Clear & $\begin{array}{l}\text { Homogen } \\
\text { eous }\end{array}$ & 1.043 & 1.91 & 369.49 \\
\hline & 2 & $\begin{array}{l}\text { Shape : Liquid } \\
\text { Color: Dark } \\
\text { brown } \\
\text { Smell: Aromatic } \\
\text { Typical } \\
\text { Taste: Soft not } \\
\text { sticky }\end{array}$ & 6 & Clear & $\begin{array}{l}\text { Homogen } \\
\text { eous }\end{array}$ & 1.06 & 1.63 & 274.87 \\
\hline & 3 & $\begin{array}{l}\text { Shape: Liquid } \\
\text { Color: Dark } \\
\text { brown } \\
\text { Smell: Aromatic } \\
\text { Typical } \\
\text { Taste :Soft not } \\
\text { sticky }\end{array}$ & 6 & Clear & $\begin{array}{l}\text { Homogen } \\
\text { eous }\end{array}$ & 1.067 & 1.58 & 209.69 \\
\hline $\begin{array}{l}\text { Informa } \\
\text { Formula } \\
\text { Formula } \\
\text { Formula }\end{array}$ & $\begin{array}{l}\text { n: } \\
\text { Foo } \\
\text { Foo } \\
\text { Foo }\end{array}$ & $\begin{array}{l}\text { anitizer Spray with } \\
\text { anitizer Spray with } \\
\text { anitizer Spray with }\end{array}$ & $\begin{array}{l}\text { stir } \\
\text { irri } \\
\text { stir }\end{array}$ & $\begin{array}{l}\text { speed o } \\
\text { seed of } \\
\text { speed o }\end{array}$ & $\begin{array}{l}0 \mathrm{rpm} \\
0 \mathrm{rpm} \\
00 \mathrm{rpm}\end{array}$ & & & \\
\hline
\end{tabular}

Based on organoleptic testing, it shows that all formulas have a liquid form, have a dark brown color, have an aromatic smell and have a soft taste that is not sticky.

\subsection{Testing the ph of the foot sanitize spray}

$\mathrm{PH}$ testing is carried out to find out what the acidity value of the preparations has been made [6]. Acidity $(\mathrm{pH})$ is measured with a $\mathrm{pH}$ meter. Topical preparations should be in the skin $\mathrm{pH}$ range, between $4.5-6.5$. The $\mathrm{pH}$ value should not be too acidic because it can irritate the skin and also should not be too alkaline because it can cause scaly skin, this is due to damage to the mantle in the stratum corneum of the skin[7]. Each foot sanitizer Spray has a $\mathrm{Ph}$ value of 6 . The $\mathrm{Ph}$ value is still within the ideal $\mathrm{pH}$ range.

\subsection{Clarity testing foot sanitize spray}

Visual testing of Foot sanitizer Spray preparations is usually performed by someone examining a clean container from the outside under good lighting, obstructed from reflection into his eyes, and on a black and white background, with the series of contents being executed 
in a circular action, must be absolutely completely free of small particles that can be seen with the eye [8]. The test results of foot sanitizer Spray are tabulated in table 4.

All Footsanitizer Spray formulas can be seen directly with the naked eye, no visible particles that are insoluble in the Footsanitizer Spray preparation. This proves that the Footsanitizer Spray preparation has good clarity. A preparation in the form of a solution or liquid is said to have good clarity if there are no visible particles that are insoluble in the solution when seen with the naked eye [8].

\subsection{Homogeneity testing footsanitizer spray}

The homogeneity test is carried out in order to determine whether the preparations made are evenly mixed or not. A good preparation must be homogeneous and free from clumped particles. To be sure, a homogeneity test was carried out [9]. The test is carried out by smearing the preparation on a glass object, then covering it with a deck glass. Then observed with a $40 \mathrm{x}$ 10 magnification microscope [10]. The test results show that all formulas are homogeneous.

\subsection{Testing the density of footsanitizer spray}

Determination of specific gravity using pycnometer. and based on the ratio of the weight of the liquid in the air at $25^{\circ} \mathrm{C}$ to the weight of water with the same volume and temperature. Specific gravity is used as an analytical method to determine liquid compounds, test the identity and purity of medicinal compounds, especially liquids, and to determine the level of solubility / solubility of a substance [11].

The lowest specific gravity value is in formula 1 with a stirring speed of $500 \mathrm{rpm}$ and the highest is in formula 3 with a stirring speed of $1500 \mathrm{rpm}$. This is because at the stirring speed of $500 \mathrm{rpm}$ the solution has not been completely mixed so that in the formulsion process only a few ingredients react. Whereas at the stirring speed of $1500 \mathrm{rpm}$, the stirring becomes too fast so that it can cause more foam, thus hindering the process of separating the mixture, which causes the density to be higher.

\subsection{Testing the viscosity of footsanitizer spray}

The viscosity test is carried out to determine how much the consistency of the preparation is and to show the thickness of a preparation that is measured with a viscometer. The spray preparation made is expected to follow Newton's liquid flow properties rules. Preparations that follow Newton's liquid rules provide the best profile when used, i.e. they are easy to remove from storage containers. Newton's flow profile can help push liquid preparations out more easily as in sprays made without the use of propellants. A fluid that follows Newton's flow rules shows a standard linear relationship between shear stress and shear rate. Some of the fluids included in the Newtonian school include water, organic solvents, as well as glycerin.

For these fluids, when comparing shear rates and shear stress, we will get [12]. Besed on the results of the viscosity test, it shows that the viscosity value decreases with increasing stirring speed.

\subsection{Antibacterial activity test for footsanitizer spray}

Testing for antibacterial activity using the agar diffusion method. This method is generally often used compared to other methods because the diffusion method makes it easier to determine 
the antimicrobial activity of a preparation by forming a zone of inhibition of bacterial growth from substances that are antibacterial in solid media. The area of inhibition for bacterial growth is the clear area around the disc. the stronger the antibacterial activity, the wider the inhibition area [13]. Antibacterial testing is one thing that needs to be done to determine the effectiveness of Footsanitizer Spray on the inhibition of bacteria on the skin of the feet such as Staphylococcus epidermidis.

\section{Conclusion}

The formulation of Footsanitizer Spray, a combination of coffee bean extract and ginger root, has been successfully formulated. Based on organoleptic testing, all Footsanitizer Spray formulas are liquid, light brown in color, have a distinctive aromatic odor and have a soft taste. The Footsanitizer Spray preparation also has good clarity and homogeneity. The results of the specific gravity test of the three formulas, namely formula 1, formula 2 and formula 3 respectively, are 1,043 grams / $\mathrm{ml}, 1,060$ grams / $\mathrm{ml}$, and 1,067 grams / $\mathrm{ml}$. while the viscosity values were $1.91 \mathrm{cp}, 1.63 \mathrm{cp}$, and $1.58 \mathrm{cp}$, respectively. formula 3 with stirring $1500 \mathrm{rpm}$ has better antibacterial activity compared to other formulas.

\section{References}

[1] Y. Siskawati, I. Bernadette, and S. L. Menaldi, "Patogenesis Dan Penatalaksanaan Bau Badan,” Dep. Ilmu Kesehat. kulit dan Kelamin FK Univ. Indones. RSUPN dr. Cipto Mangunkusumo Jakarta, vol. 41, no. 71, pp. 32-41, 2014.

[2] Wilda Amananti and A. B. Riyanta, "Karakteristik Fisik Sediaan Foot Sanitizer Spray Kombinasi Ekstrak Biji Kopi ( Coffea ) Dan Rimpang Jahe ( Zingiber Officinale ) Dengan Varisasi Kecepatan Dan Waktu Pengadukan," vol. 6, no. 1, pp. 92-97, 2020.

[3] J. Limantara, P. E. D. Tedjokoesoemo, and M. T. Rizqy, "Penggunaan Ampas Kopi Sebagai Material Alternatif pada Produk Interior," J. Intra, vol. 7, no. 2, pp. 846-849, 2019.

[4] A. Hamad, W. Anggraeni, and D. Hartanti, "Potensi Infusa Jahe ( Zingiber officinale R ) sebagai Bahan Pengawet Alami pada Tahu dan Daging Ayam Segar," J. Apl. Teknol. Pangan, vol. 6, no. 4, pp. 177-183, 2017.

[5] S. R. Pakadang and H. Salim, "Kombinasi Daun Miana (Coleus scutellarioides (L.) Benth) dan Rimpang Jahe (Zingiber officinale Rosc.) sebagai antibakteri Streptococcus pneumonia, Staphylococcus aureus, Staphylococcus epidermidis, Klebsiella pneumonia Penyebab Batuk," Media Farm., vol. 15, no. 1, p. 1, 2019, doi: 10.32382/mf.v15i1.779.

[6] P. P. Vol, “جنرب در كلمء و زرهي (Oryza sativa ),” vol. 30, no. 3, pp. 494-504, 2016.

[7] S. A. Mardikasari, M. Jufri, and J. Djajadisastra, "Formulasi dan Uji Penetrasi In-Vitro Sediaan Topikal Nanoemulsi Genistein dari Tanaman Sophora japonica Linn. (Formulation and In-Vitro Penetration Study of Topical Dosage Form of Nanoemulsion from Genistein of Sophora japonica Linn.),” J. Ilmu Kefarmasian Indones., vol. 14, no. 2, pp. 190-198, 2016.

[8] K. M. Cabrera Marino, "Инновационные подходы к обеспечению качества в здравоохраненииNo Title,” Вестник Росздравнадзора, vol. 6, no. 2, pp. 5-9, 2017.

[9] A. Setiawan, R. D. Ayatri, N. Niswantari, and N. Rusli, "Penggunaan Emulgator VCO (Virgin Coconut Oil) Dalam Sediaan Krim transdermal Asetosal,” War. Farm., vol. 8, no. 2, pp. 81-90, 2019, doi: 10.46356/wfarmasi.v8i2.120. 
[10] L. Nurdianti, "Evaluasi Sediaan Emulgel Anti Jerawat Tea Tree (Melaleuca alternifolia) Oil Dengan Menggunakan Hpmc Sebagai Gelling Agent,” J. Pharmacopolium, vol. 1, no. 1, pp. 23-31, 2018, doi: 10.36465/jop.v1i1.392.

[11] E. Mumpuni, A. Purwanggana, E. Mulatsari, and R. Pratama, "Formulasi dan Evaluasi Larutan Pencuci Mulut dengan Bahan Antimikroba Senyawa 1,5-Bis (3'-Etoksi-4'-Hidroksifenil)-1,4Pentadien-3-on," J. Ilmu Kefarmasian Indones., vol. 17, no. 1, p. 87, 2019, doi: 10.35814/jifi.v17i1.615.

[12] R. Iswandana and L. K. Sihombing, "Formulation, physical stability, and in vitro activity test of foot odor spray with betel leaf etanol extract (Piper betle L.)," Pharm. Sci. Res., vol. 4, no. 3, pp. 121 131, 2017, doi: 10.7454/psr.v4i3.3805.

[13] S. J. N. Fitri Handayani, Husnul Warnida, "Formulasi Dan Uji Aktivitas Antibakteri Streptococcus mutans Dari Sediaan Mouthwash Ekstrak Daun Salam (Syzygium polyanthum (Wight) Walp.)," J. Chem. Inf. Model., vol. 53, no. 9, pp. 1689-1699, 2016. 